\title{
Relation Of Disease Activity With Quality Of Life and Sleep Quality In Knee Osteoarthritis
}

\section{Diz Osteoartritinde Hastalık Aktivitesinin Yaşam Kalitesi ve Uyku Kalitesi Ille lilş̧isi}

\author{
Volkan Şah \\ Van Yü̊üncü Yal Üniversitesi Hastanesi, Spor Hekimliği Ana Bilim Dal, Van, Türkiye
}

\begin{abstract}
Introduction: The aim of this study was to assess the relation of disease activity with quality of life and sleep quality in knee osteoarthritis.

Methods: The study was performed on patients with knee osteoarthritis ( $\mathrm{n}=100 ; 28$ males, 72 females; mean age 58.09 years; range 23 to 85 years). Kellgren-Lawrence (KL) classification system, Visual Analog Scale (VAS), Western Ontario and McMaster Universities Osteoarthritis Index (WOMAC), World Health Organization Quality of Life (WHOQOL-BREF), and Pittsburgh Sleep Quality Index (PSQI) were used to evaluate radiological grading, pain, physical function (disease activity), quality of life, and sleep quality, respectively.

Results: There were significant positive correlations among $\mathrm{KL}$, VAS, WOMAC, and PSQI scores, while significant negative correlations were found between WHOQOL-BREF profiles and KL, VAS, WOMAC, and PSQI scores (all $\mathrm{p}<$ $0.01)$.

Conclusion: Our results suggest that higher disease activity is related to lower quality of life and poorer sleep quality in knee osteoarthritis.
\end{abstract}

Key Words: osteoarthritis, knee pain, quality of life, sleep quality

\section{Introduction}

Knee osteoarthritis is the most common painful articular disease and exhibits a heterogeneity in terms of underlying pathophysiological mechanisms and phenotypic characteristics (1). It is associated with high burden and disability rates and such rates vary depending on sociodemographic factors (2). Also, knee osteoarthritis has various harmful effects on health (3). There are various treatment options including pharmacological, surgical, and nonpharmacological and surgical interventions for knee osteoarthritis (4).

Previous studies have shown that knee osteoarthritis is related to both low quality of life and poor sleep

\section{ÖZET}

Amaç: $\mathrm{Bu}$ çalışmanın amacı diz osteoartritinde hastalık aktivitesinin yaşam kalitesi ve uyku kalitesi ile ilișkisini değerlendirmektir.

Yöntem: Bu çalışma diz osteoartriti olan hastalar üzerinde yapıldı ( $\mathrm{n}=100 ; 28$ erkek, $72 \mathrm{kadın;} \mathrm{ort.} \mathrm{yaş} 58.09$ yıl; dağılım 23-85 y1). Kellgren-Lawrence (KL) sinıflandırma sistemi, Görsel Analog Skala (VAS), Western Ontario ve McMaster Üniversiteleri Osteoartrit İndeksi (WOMAC), Dünya Sağlık Örgütü Yaşam Kalitesi (WHOQOL-BREF) ve Pittsburgh Uyku Kalitesi Endeksi (PSQI) sirasiyla radyolojik derecelendirme, ağı, fiziksel fonksiyon (hastalık aktivitesi), yaşam kalitesi ve uyku kalitesini değerlendirmek için kullanılmıştır.

Bulgular: KL, VAS, WOMAC ve PSQI skorları arasinda anlamlı pozitif, WHOQOL-BREF profilleri ile KL, VAS, WOMAC ve PSQI skorları arasında anlamlı negatif korelasyon bulundu (tümü $\mathrm{p}<0.01$ ).

Sonuçlar: Sonuçlarımız diz osteoartritinde daha yüksek hastalık aktivitesinin daha düşük yaşam kalitesi ve daha kötü uyku kalitesi ile ilgili olduğunu göstermektedir.

Anahtar Kelimeler: Osteoartrit, diz ağrısı, yaşam kalitesi, uyku kalitesi

quality (3,5). Nevertheless, investigation or confirmation of such data in different societies and different times is important, because there are racial/ethnic differences in knee osteoarthritis-related pain and disability $(6,7)$. Therefore, this study aimed to address the relation of disease activity with quality of life and sleep quality in knee osteoarthritis.

\section{Material and Methods}

In accordance with the principles of the Declaration of Helsinki, the study was performed at our Department of Physical Medicine and Rehabilitation. The Local Ethics Committee approved the study protocol (Decision No: 2009-08; Date: June 26, 
Table 1. Participants Characteristics

\begin{tabular}{lc}
\hline & Patients with knee osteoarthritis $(\mathrm{n}=100)$ \\
\hline Age, years & $58.09 \pm 12.64(23-85)$ \\
Gender, F/M & $72 / 28$ \\
Disease duration, years & $10.67 \pm 3.41(3.0-18.4)$ \\
VAS, motion & $84.25 \pm 13.71(50-100)$ \\
WOMAC, total & $61.17 \pm 13.74(32-89)$ \\
PSQI & $13.31 \pm 4.41(3.0-20.0)$ \\
WHOQOL-BREF & \\
Physical health & $42.16 \pm 14.97(10.0-76.0)$ \\
Psychological & $47.90 \pm 13.88(11.0-76.0)$ \\
Social relationships & $45.61 \pm 18.83(12.0-85.0)$ \\
Environment & $51.01 \pm 16.23(13.0-89.0)$ \\
\hline
\end{tabular}

F/M: Female/Male; VAS: Visual analogue scale; WOMAC: Western Ontario and McMaster Universities Osteoarthritis Index; PSQI: Pittsburgh Sleep Quality Index (PSQI); WHOQOL-BREF: World Health Organization Quality of Life; Values were given as mean $\pm \mathrm{SD}$ (min. - max.) or number

2009), and written informed consent was obtained from each participant.

A total of 100 knee osteoarthritis patients ( 28 males, 72 females; mean age 58.09 years; range 23 to 85 years) diagnosed according to American College of Rheumatology criteria (8) were evaluated in this study. Visual Analog Scale (VAS) (9), Kellgren-Lawrence (KL) radiological classification system (10), Western Ontario and McMaster Universities Osteoarthritis Index (WOMAC) (11), World Health Organization Quality of Life (WHOQOL-BREF) (12), and Pittsburgh Sleep Quality Index (PSQI) (13) scores were used to evaluate pain, radiological grading, physical function, quality of life, and sleep quality, respectively.

The KL classification represents radiographic severity of osteoarthritis according to presence of osteophyte formation, narrowing of the joint space, subchondral sclerosis, and deformity of bony ends (10). The WOMAC index is a questionnaire developed to assess disease activity in patients with hip or knee osteoarthritis, and consists of 24 questions evaluating pain, stiffness, and physical function (11). The WHOQOL-BREF contains 26 items, and addresses four domains (physical health, psychological, social relationships, environment) (12). The PSQI contains 19 items assessing sleep quality and sleep disturbances over one-month time interval (13). Higher scores in VAS, KL, WOMAC, and PSQI, while lower scores in WHOQOL-BREF are associated with worsening status (9-13).

The knee joint with greater pain was included in the evaluations, but right knee was evaluated when the pain severity was equal in both knees. The knee pain intensity, VAS score, was measured after $20 \mathrm{~m}$ walking. Patients with grade 2-3-4 knee osteoarthritis according to $\mathrm{KL}$ radiological rating scale and who suffering from knee pain VAS score $\geq 50 \mathrm{~mm}$ were included in the study.

Patients who have the following medical conditions were excluded: inflammatory joint disorders, use of corticosteroid and/or hyaluronic acid within the last three months, history of physical therapy or antidepressant use within the last six months, history of knee surgery, serious and decompensated systemic disease, presence or history of malignancy, diabetes mellitus, restless leg syndrome, polyneuropathy, and fibromyalgia syndrome.

Statistical analysis: All statistics were calculated by SPSS, version 13.0 software program (SPSS Inc., Chicago, IL, USA). The Student's t test was used to compare continuous variables, while the Chi-square test was used to compare categorical variables. The Pearson's correlation test was applied for correlation analyses. Continuous data were presented as mean (min.-max.) and categorical variables were presented as number. A p-value is less than 0.05 was considered as statistically significant.

\section{Results}

Table 1 demonstrates patients characteristics including age, sex, disease duration, VAS, WOMAC, PSQI, and WHOQOL-BREF scores.

Table 2 presents correlation analyses: There were significant positive correlations between KL scores and VAS, WOMAC, and PSQI scores, while significant negative correlations were found between KL scores and WHOQOL-BREF profiles (all $\mathrm{p}<$ 0.01). There were significant positive correlations between VAS scores and WOMAC, and PSQI scores, while significant negative correlations were found 
Table 2. Correlation analyses

\begin{tabular}{lcccc}
\hline & KL & VAS & WOMAC & PSQI \\
\hline KL & & & & \\
VAS & $0.492^{*}$ & & & \\
WOMAC & $0.716^{*}$ & $0.750^{*}$ & & \\
PSQI & $0.685^{*}$ & $0.702^{*}$ & $0.823^{*}$ & \\
Physical health & $-0.574^{*}$ & $-0.64 * \Omega$ & $-0.690^{*}$ & $-0.760^{*}$ \\
Psychological & $-0.624^{*}$ & $-0.538^{*}$ & $-0.682^{*}$ & $-0.701^{*}$ \\
Social relation & $-0.550^{*}$ & $-0.554^{*}$ & $-0.708^{*}$ & $-0.721^{*}$ \\
Environment & $-0.603^{*}$ & $-0.492^{*}$ & $-0.661^{*}$ & $-0.649^{*}$ \\
\hline
\end{tabular}

*: p<0.01; KL: Kellgren-Lawrence; VAS: Visual analogue scale; WOMAC: Western Ontario and McMaster Universities Osteoarthritis Index; PSQI: Pittsburgh Sleep Quality Index

between VAS scores and WHOQOL-BREF profiles (all $\mathrm{p}<0.01$ ). There were significant positive correlations between WOMAC and PSQI scores, while significant negative correlations were found between WOMAC scores and WHOQOL-BREF profiles (all $\mathrm{p}<0.01$ ). Also, the correlations between PSQI scores and WHOQOL-BREF profiles were significantly negative (all $\mathrm{p}<0.01$ ).

\section{Discussion}

In this study, we aimed to address the relation of disease activity with quality of life and sleep quality in knee osteoarthritis. For this purpose, we used appropriate assessment scales including VAS, KL, WOMAC, PSQI, and WHOQOL-BREF. As a result, we found that as disease activity increases, quality of life and sleep quality decrease in knee osteoarthritis.

There are racial/ethnic differences in knee osteoarthritis-related pain and disability $(6,7)$, and the rates of burden and disability vary depending on sociodemographic factors of knee osteoarthritis patients (2). Also, knee osteoarthritis is related to genetic and biomechanic characteristics $(14,15)$. Therefore, although previous studies on the topic have shown that knee osteoarthritis is associated with both low quality of life and poor sleep quality $(3,5)$, to address such subject in different societies and different times is important.

To date, many studies performed on different societies have revealed significant relationship between knee osteoarthritis and sleep quality and quality of life $(3,5,16,17)$. In accordance with the results of these studies, our study showed and confirmed that higher disease activity is associated with lower quality of life and poorer sleep quality in knee osteoarthritis patients. It has been reported that many chronic pain conditions affect quality of life and sleep quality negatively $(18,19)$. In addition, some health problems-related to knee osteoarthritis such as overweight and obesity (20) are also associated with low scores pertaining both sleep and life qualities (21). Therefore, chronic painful in nature of knee osteoarthritis and its coexistence with various health problems can explain underlying causal mechanisms for worsening quality of life and sleep quality in knee osteoarthritis patients.

On the other hand, there are some potential limitations to this study that should be taken into account. The present study was performed with grade 2-3-4 knee osteoarthritis according to KL classification. For this reason, our results may not valid for early stage of knee osteoarthritis. Another limitation may be related to the assessment scales which are based on self-reported data used to evaluate pain intensity, physical function, quality of life, and sleep quality.

In conclusion, as disease activity increases, quality of life and sleep quality decrease in patients with knee osteoarthritis. Clinicians dealing with knee osteoarthritis should be consider these important relations.

\section{References}

1. Dell'Isola A, Steultjens M. Classification of patients with knee osteoarthritis in clinical phenotypes: Data from the osteoarthritis initiative. PLoS One 2018; 13(1): 0191045.

2. Liu Q, Wang S, Lin J, Zhang Y. The burden for knee osteoarthritis among Chinese elderly: estimates from a nationally representative study. Osteoarthritis Cartilage 2018; 26(12): 1636-1642.

3. Wilson R, Blakely T, Abbott JH. Radiographic knee osteoarthritis impacts multiple dimensions of health-related quality of life: data from the Osteoarthritis Initiative. Rheumatology (Oxford) 2018; 57(5): 891899. 
4. Ferreira RM, Duarte JA, Gonçalves RS. Nonpharmacological and non-surgical interventions to manage patients with knee osteoarthritis: An umbrella review. Acta Reumatol Port 2018; 43(3): 182-200.

5. Fertelli TK, Tuncay FO. Fatigue in individuals with knee osteoarthritis: Its relationship with sleep quality, pain and depression. Pak J Med Sci 2019; 35(4): 10401044.

6. Cruz-Almeida Y, Sibille KT, Goodin BR, Petrov ME, Bartley EJ, Riley JL 3rd, et al. Racial and ethnic differences in older adults with knee osteoarthritis. Arthritis Rheumatol 2014; 66(7): 1800-1810.

7. Vaughn IA, Terry EL, Bartley EJ, Schaefer $\mathrm{N}$, Fillingim RB. Racial-Ethnic Differences in Osteoarthritis Pain and Disability: A MetaAnalysis. J Pain 2019; 20(6): 629-644.

8. Altman RD. Criteria for classification of clinical osteoarthritis. J Rheumatol Suppl 1991; 27: 10-12.

9. Rejeski WJ, Ettinger WH, Shumaker S, Heuser MD, James P, Monu J, et al.The evaluation of pain in patients with knee osteoarthritis: the knee pain scale. J Rheumatol 1995; 22: 1124-1129.

10. Kellgren JH and Lawrence JS. Radiological assessment of osteo-arthrosis. Ann Rheum Dis 1957; 16: 494-502.

11. Tüzün EH, Eker L, Aytar A, Daşkapan A, Bayramoğlu M. Acceptability, reliability, validity and responsiveness of Turkish version of WOMAC osteoarthritis index. Osteoarthritis Cartilage 2005; 13(1): 28-33.

12. Eser SY, Fidaner H, Fidaner C, Elbi H, Eser E, Göker E. Yaşam kalitesinin ölçülmesi WHOQOL 100 ve WHOQOL-Bref. Psikiyatri Psikoloji ve Psikofarmakoloji dergisi 1999; 7(2): 5-13.

13. Agargun MY, Kara H, Anlar O. Pittsburgh uyku kalitesi indeksi'nin geçerliliği ve güvenilirliği. Türk Psikiyatri Dergisi 1996; 7(2): 107-115.
14. Vina ER, Kwoh CK. Epidemiology of osteoarthritis: literature update. Curr Opin Rheumatol 2018; 30(2): 160-167.

15. van Tunen JAC, Dell'Isola A, Juhl C, Dekker J, Steultjens M, Thorlund JB, et al. Association of malalignment, muscular dysfunction, proprioception, laxity and abnormal joint loading with tibiofemoral knee osteoarthritis - a systematic review and meta-analysis. BMC Musculoskelet Disord 2018; 19(1): 273.

16. Bindawas SM, Vennu V, Alfhadel S, AlOtaibi AD, Binnasser AS. Knee pain and health-related quality of life among older patients with different knee osteoarthritis severity in Saudi Arabia. PLoS One 2018; 13(5): e0196150.

17. Sasaki E, Tsuda E, Yamamoto Y, Maeda S, Inoue R, Chiba D, et al. Nocturnal knee pain increases with the severity of knee osteoarthritis, disturbing patient sleep quality. Arthritis Care Res (Hoboken) 2014; 66(7): 1027-1032.

18. Husky MM, Ferdous Farin F, Compagnone P, Fermanian C, Kovess-Masfety V. Chronic back pain and its association with quality of life in a large French population survey. Health Qual Life Outcomes 2018; 16(1): 195.

19. Keilani M, Crevenna R, Dorner TE. Sleep quality in subjects suffering from chronic pain. Wien Klin Wochenschr 2018; 130(1-2): 31-36.

20. Reyes C, Leyland KM, Peat G, Cooper C, Arden NK, Prieto-Alhambra D. Association Between Overweight and Obesity and Risk of Clinically Diagnosed Knee, Hip, and Hand Osteoarthritis: A Population-Based Cohort Study. Arthritis Rheumatol 2016; 68(8): 18691875.

21. Turco G, Bobbio T, Reimão R, Rossini S, Pereira H, Barros Filho A. Quality of life and sleep in obese adolescents. Arq Neuropsiquiatr 2013; 71(2): 78-82. 